\title{
Grafikus felület készítése épületek energiafogyasztásának szimulációs vizsgálatához
}

\author{
Tyukodi Zsolt \\ Mechatronikai Tanszék \\ Debreceni Egyetem, Müszaki Kar \\ Debrecen, Magyarország \\ tyukodi.zsolt95@gmail.com
}

\author{
Sarvajcz-Bánóczy Emese \\ Mechatronikai Tanszék \\ Debreceni Egyetem, Müszaki Kar \\ Debrecen, Magyarország \\ emese.banoczy@eng.unideb.hu
}

\author{
Dr. habil Husi Géza \\ Mechatronikai Tanszék \\ Debreceni Egyetem, Müszaki Kar \\ Debrecen, Magyarország \\ husigeza@eng.unideb.hu
}

\begin{abstract}
Absztrakt- Ezen kutatás keretein belül egy lakóépület energetikai szimulációja történt EnergyPlus programmal. Az épületre több változat is készíthető egy SciLab alkalmazással, mellyel az EPISCOPE program keretein belül készített Lakóépület tipológia Magyarországon kiadványban javasolt felújítási módosítások szerint változtathatjuk az épületszerkezetet. Ezen kívül további alkalmazások készültek a szimulációs eredmények megjelenítésére és energetikai tanúsítványhoz szükséges adatok számítására.
\end{abstract}

Kulcsszavak-EnergyPlus, SciLab, TABULA-EPISCOPE, épületenergetikai szimuláció, energetikai tanúsítvány

\section{BEVEZETÖ}

A magyarországi épületállomány energetikai állapotáról ad tájékoztatást a Lakóépület tipológia Magyarországon kiadvány, mely azt feltételezi, hogy az adott épülettípusok építésük óta nem lettek felújítva. Belátható, hogy az épülettípusok korából adódóan az épületeket legalább részlegesen felújították. A feladat készítése során a cél egy olyan alkalmazás fejlesztése volt, mellyel a kiadványban szereplő épülettípusoktól eltérő, vagy részlegesen felújított épületek energetikai jellemzőit határozhatjuk meg.

Az alkalmazással egy Hosszúpályiban lévő családi ház alapján egy épület energetikai tulajdonságait határozzuk meg szimulációs módszerrel. A szimulációt az EnergyPlus nevü szoftverrel végezzük. Az alkalmazást a SciLab programban készítjük el, melyen az épülettipológia kiadványban javasolt általános és mélyfelújítás alapján megváltoztatott épületszerkezeteket választhatunk ki. Az alkalmazás a módosításoknak megfelelően elkészíti az épület szimulációs modelljét, melyet a szimulációs szoftver bemeneti fájlként használ. A szimuláció lefuttatása után az alkalmazás az eredmények megjelenítésére is alkalmas.

\section{ELÖZMÉNYEK}

\section{A. A magyarországi épülettipológia bemutatása}

A teljes energiafelhasználás megközelítőleg 40 százalékát az épületek energiafogyasztása teszi ki. Az épületszektorban jelentős energiamegtakarítás érhető el, az ehhez szükséges energiapolitikai célok meghatározásához elengedhetetlenek a megfelelő részletességü információk az épületállomány energiafelhasználásáról. Ennek érdekében az Intelligens
Energia Európa program által támogatott EPISCOPE projekt keretében Magyarországon is elkészült az országra jellemző épülettipológia. Az épületeket a TABULA módszertan alapján tipologizálták, Magyarországon a Budapesti Müszaki és Gazdaságtudományi Egyetem oktatói és kutatói. [1]

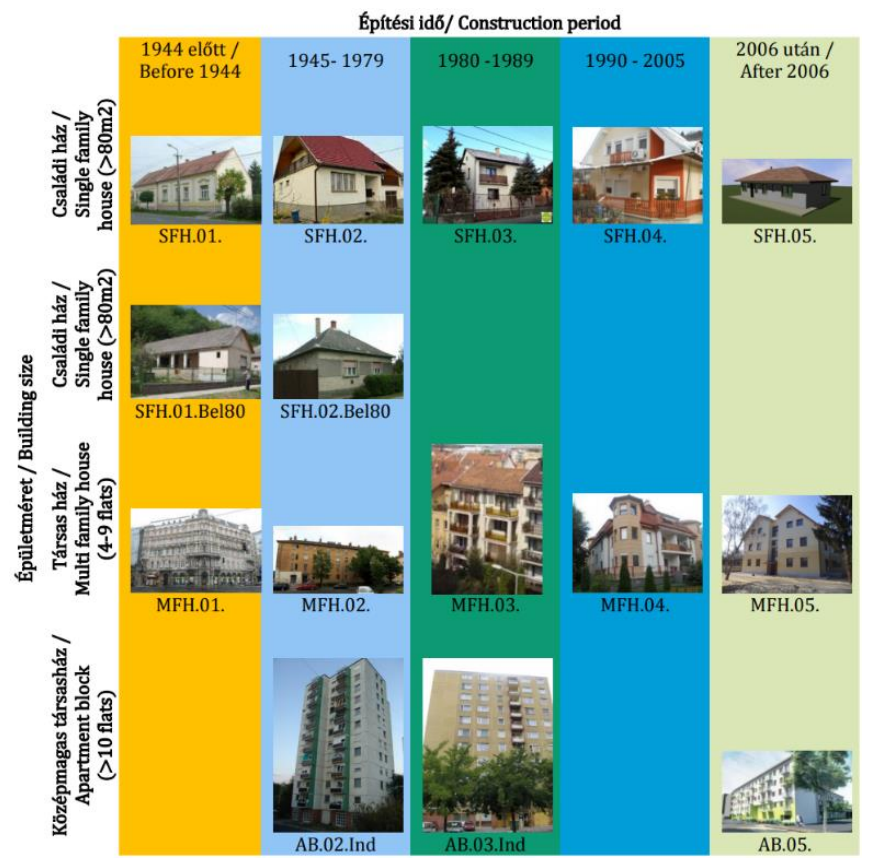

1. ábra: A magyarországi lakóépületek tipológiája, épülettipológiai mátrix [1]

Az épületek besorolásának szempontjai:

- $\quad$ ország;

- $\quad$ régió (országos, vagy egy adott régió);

- építés éve;

- $\quad$ épület mérete;

- $\quad$ egyéb tényezők.

Az épületek méret szerinti osztályozása (az angol nyelvü rövidítéssel)

- $\quad$ családi ház (SFH); 
- $\quad$ sorházas beépítésü családi ház (TFH);

- $\quad$ társasház (MFH);

- $\quad$ középmagas társasház $(\mathrm{AB})$.

A kiadvány tartalmazza az épülettípusok jellemző adatait (építési idő, szintszám, nettó alapterület, fütött térfogat, stb.), tájékoztat a meglévő (felújítás nélküli) állapotról, az általános és mélyfelújítás során elvégzett változtatásokról. Ezek mellett táblázat foglalja össze az épület külső határoló szerkezeteinek rétegrendjeit, hőátbocsátási tényezőit, a használt épültgépészeti rendszert és annak teljesítménytényezőjét. Minden épülettípusnál grafikonok ábrázolják az eredeti állapot, az általános felújítás és a mélyfelújítás szerint TABULA módszertan alapján számított eredményeket. A tipológia mellett statisztikai adatokat is rendeltek a kiadványhoz az országos épületállományt érintő vizsgálatokhoz az épülettípusok darabszámát, fütési rendszereit és a jellemző felújítási gyakorlatot illetően. [1]

\section{B. Az épületenergetikai modellezö szoftver bemutatása}

Az EnergyPlus és az OpenStudio projekt az Egyesült Államok Energiaügyi Minisztériumának épületenergetikai modellező portfóliójának tagjai. Az EnergyPlus egy épületenergetikai szimulációs motor, mely fejlesztését a DOE2.1E utódjaként 1997 óta végzik a National Renewable Energy Laboratory, az Energiaügyi Minisztérium, egyetemi intézmények és magáncégek együttmüködésével. $\mathrm{Az}$ Energyplus épületek energia és víz felhasználásának modellezésére használható. Egy konzol alapú program, amely szöveges fájlokat olvas bemenetként és hoz létre kimenetként.

A motorhoz számos segédprogram áll rendelkezésre többek között bemeneti fájl létrehozására, a be- és kimeneti fájlok kezelésére, szimuláció végrehajtására, szimulációs eredmények grafikus összehasonlítására, továbbá számos grafikus kezelőfelület. $\mathrm{Az}$ EnergyPlus az OpenStudio szoftverfejlesztő készlettel készült. Az OpenStudio nyílt forráskódú projekt részeként EnergyPlust használó épületenergetikai modellezést támogató szoftvereszközök készültek. Ilyen eszköz a SketchUp programhoz készült bővítmény, mellyel épületek 3D modelljéből EnergyPlus bemeneti fájl készíthető. [2] [3] [4]

\section{A Scilab bemutatása}

A SciLab szoftver kezdete a 80 -as évekre vezethető vissza a francia INRIA cégnél, a föként François Delebecque és Serge Steer által fejlesztett Matlab által inspirált szoftverként Blaise néven. A 90-es években a fejlesztés Scilab néven folytatódott, később már nyílt forráskódú szoftverként. Jelenleg a szoftverfejlesztő cég felvásárlásával a fejlesztés az ESI Grouphoz került, a szoftver továbbra is nyílt forráskódú és ingyenes. A Scilab egy mátrixalapú matematikai szoftver és programozási nyelv, mely a MATLAB nyelven alapul. A szoftver a MATLAB programcsomag ingyenes alternatívája, de szintaktikailag nem teljesen kompatibilisek. Matematikai müveletek mellett többek között 2 és 3 dimenziós vizualizációra, adatelemzésre, jelfeldolgozásra és vezérlő rendszerek vizsgálatára is képes. [5]

\section{Az épület bemutatása:}

A modellezett épület Hosszúpályi belterületén álló 640 helyrajzi számú családi ház. Az épület tulajdonságait tekintve leginkább az országos épülettipológia szerinti SFH.02.Bel80 típusú épülettel egyezik. A típusépület és a modellezett épület hötechnikai adatait az 1. táblázat foglalja össze. Az épület jelenleg az eredeti állapottól eltér, az ablakok és ajtók az általános felújításnál javasolttal egyeznek meg. A használt hötermelö állandó hőmérsékletü gázkazán.

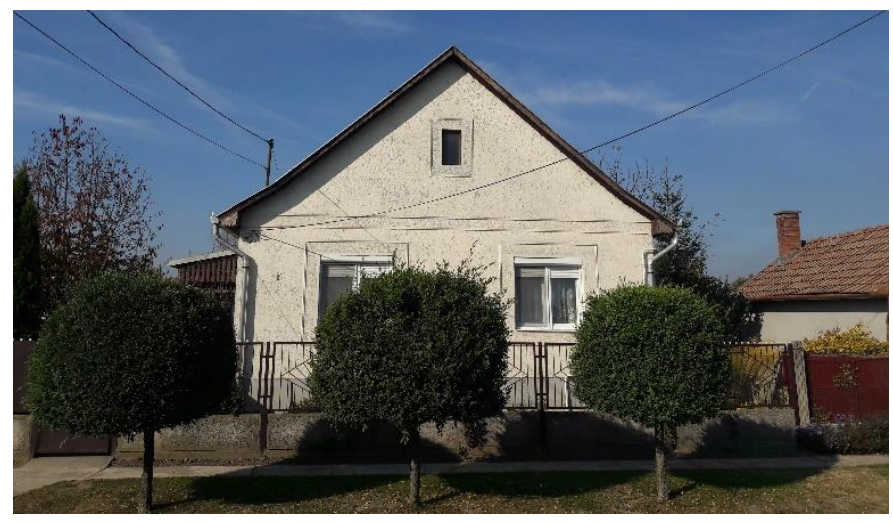

2. ábra: A modellezett épület utcai homlokzata

I. TÁBLÁZAT: Az épületszerkezetek hőátbocsátási tényezői [1]

\begin{tabular}{|c|c|c|c|c|}
\hline $\begin{array}{l}\text { Külső } \\
\text { határoló } \\
\text { szerkezetek }\end{array}$ & SFH.02.Bel60 & $\begin{array}{c}\text { Hőátbo- } \\
\text { csátási } \\
\text { tényezó } \\
\mathbf{U} \\
\left(\mathrm{W} / \mathbf{m}^{2} \mathbf{K}\right)\end{array}$ & $\begin{array}{l}\text { A } \\
\text { modellezett } \\
\text { épület }\end{array}$ & $\begin{array}{c}\text { Hőátbo- } \\
\text { csátási } \\
\text { tényezó } \\
\mathbf{U} \\
\left(\mathrm{W} / \mathbf{m}^{2} \mathbf{K}\right)\end{array}$ \\
\hline \multirow{3}{*}{ Fal } & Eredeti & 1,36 & Eredeti & 0,96 \\
\hline & $\begin{array}{l}\text { Általános } \\
\text { felújítás }\end{array}$ & 0,5 & $\begin{array}{l}\text { Általános } \\
\text { felújítás }\end{array}$ & 0,45 \\
\hline & Mélyfelújítás & 0,17 & Mélyfelújítás & 0,17 \\
\hline \multirow{3}{*}{ Padlásfödém } & Eredeti & 1,3 & Eredeti & 1,29 \\
\hline & $\begin{array}{l}\text { Általános } \\
\text { felújítás }\end{array}$ & 0,27 & $\begin{array}{l}\text { Általános } \\
\text { felújítás }\end{array}$ & 0,27 \\
\hline & Mélyfelújítás & 0,14 & Mélyfelújítás & 0,15 \\
\hline \multirow{3}{*}{$\begin{array}{l}\text { Talajon fekvő } \\
\text { padló }\end{array}$} & Eredeti & 0,98 & Eredeti & 0,71 \\
\hline & Nincs változás & 0,98 & $\begin{array}{l}\text { Nincs } \\
\text { változás }\end{array}$ & 0,71 \\
\hline & Nincs változás & 0,98 & $\begin{array}{l}\text { Nincs } \\
\text { változás }\end{array}$ & 0,71 \\
\hline \multirow{3}{*}{ Ablak } & Eredeti & 3,00 & Eredeti & 2,00 \\
\hline & $\begin{array}{l}\text { Általános } \\
\text { felújítás }\end{array}$ & 1,60 & $\begin{array}{l}\text { Általános } \\
\text { felújítás }\end{array}$ & 1,60 \\
\hline & Mélyfelújítás & 1,00 & Mélyfelújítás & 1,00 \\
\hline \multirow{3}{*}{ Ajtó } & Eredeti & 3,50 & Eredeti & 3,50 \\
\hline & $\begin{array}{l}\text { Általános } \\
\text { felújítás }\end{array}$ & 1,80 & $\begin{array}{l}\text { Általános } \\
\text { felújítás }\end{array}$ & 1,80 \\
\hline & Mélyfelújítás & 1,30 & Mélyfelújítás & 1,30 \\
\hline
\end{tabular}

A típusépület hőátbocsátási tényezőinek értékeit az épülettipológiai kiadvány tartalmazza, a modellezett épület építőanyagainak hőtechnikai jellemzőit az MSZ-04-140: 1991 szabvány foglalja össze. A hőátbocsátási tényezőket számítással határoztuk meg a 7/2006. (V.24.) TNM rendelet szerint, a padlónál a vonalmenti hővezetési ellenállás a rendelet III.1. táblázatából olvasható le. 
A fütési rendszer a két épület esetén megegyezik. A példaépületben a használati melegvíz előállítása földgázzal történik, a modellezett épületben Hajdu Z 150 E típusú villanybojlerrel történik a melegvíz előállítása. Az épület vizsgálata során a meglévő rendszert vettünk figyelembe, melyet a felújítások során sem változtattunk.

II. TÁBLÁZAT: A fütési rendszer teljesítménytényezői [1]

\begin{tabular}{|l|c|l|c|}
\hline SFH.02.Bel60 & $\begin{array}{c}\text { Teljesítmény- } \\
\text { tényezö }\end{array}$ & A modellezett épület & $\begin{array}{c}\text { Teljesítmény } \\
\text {-tényező }\end{array}$ \\
\hline $\begin{array}{l}\text { Eredeti állapot: } \\
\text { Állandó } \\
\text { hömérsékletü } \\
\text { gázkazán }\end{array}$ & 1,30 & $\begin{array}{l}\text { Eredeti állapot: Állandó } \\
\text { hőmérsékletü gázkazán }\end{array}$ & 1,30 \\
\hline $\begin{array}{l}\text { Általános } \\
\text { felújítás: } \\
\text { Kondenzációs } \\
\text { gázkazán, } \\
\text { fordulatszámsza } \\
\text { bályozású } \\
\text { szivattyú }\end{array}$ & 1,03 & $\begin{array}{l}\text { Általános felújítás: } \\
\text { Kondenzációs gázkazán, } \\
\text { fordulatszámszabályozá } \\
\text { sú szivattyú }\end{array}$ & 1,03 \\
\hline $\begin{array}{l}\text { Mélyfelújítás: } \\
\text { Kondenzációs } \\
\text { kazán, cirkuláció }\end{array}$ & 1,03 & $\begin{array}{l}\text { Mélyfelújítás: } \\
\text { Kondenzációs kazán, } \\
\text { cirkuláció }\end{array}$ & 1,03 \\
\hline
\end{tabular}

\section{A SZIMULÁCIÓS FÁJL ELKÉSZÍTÉSE}

\section{A. A geometriai modell létrehozása:}

A SketchUp programban külön termikus zónákba készíthetjük el az azok által tartalmazott helyiségeket. Az épületszerkezetet a belső méretek alapján a lehülő felületekkel modellezhetjük. A program a megrajzolt felületekhez automatikusan hozzárendeli az alapértelmezett tulajdonságokat, melyeket az 'Object info' ablakban megváltoztathatunk. Ebben az ablakban láthatjuk a felületek bemeneti fájlban megjelenő adatainak elönézetét.

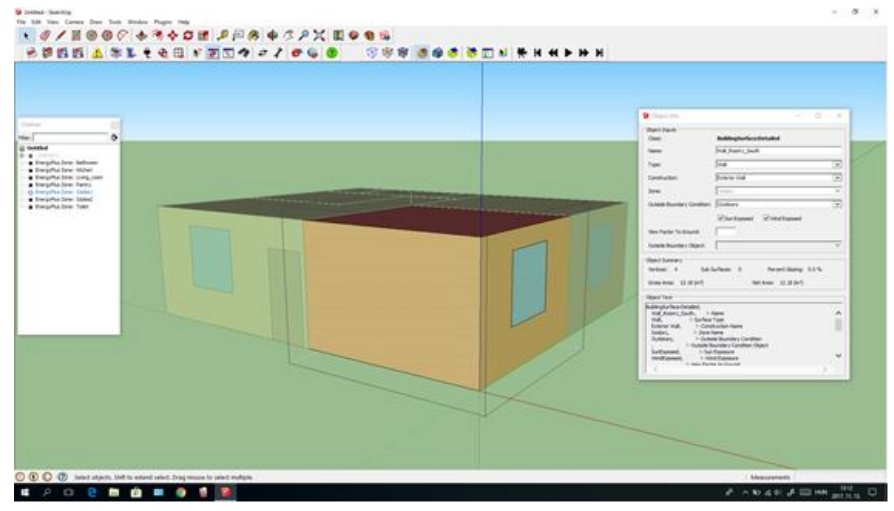

3. ábra: Az épület geometriai modellje a SketchUp programban [saját ábra]

A modellt idf kiterjesztésű fájlként elmentve hozhatjuk létre a szimulációs bemeneti fájlt, mely tartalmazza az épület felületeit a koordinátákkal és az alapértelmezetten hozzáadott adatokkal, pl anyagok, tájolás, időrendek. Ez a fájl alkalmas az EnergyPlus programcsomaghoz tartozó IDF Editor segédprogrammal, vagy szövegszerkesztővel történő szerkesztésre.

\section{B. A bemeneti fájl elkészitése}

$\mathrm{Az}$ IDFEditor program az EnergyPlus idd fájl beolvasásával teszi lehetővé az idf fájl létrehozását és szerkesztését. Az idd fájlban leírt elérhetô objektumokat listán sorolja fel a program, a listáról kiválasztva láthatjuk az objektum megadandó adatait és a mértékegységeket. A 'New Obj' gombbal adhatunk hozzá objektumokat a bemeneti fájlhoz, az objektum adatait begépelve, vagy legördülő listáról kiválasztva.

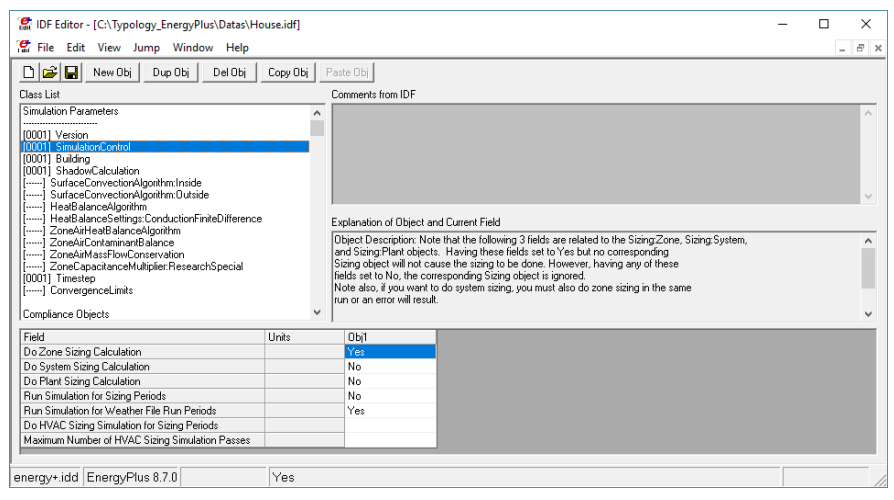

4. ábra: Az IDFEditor program felülete [saját ábra]

A szimuláció futtatásához az EP-Launch segédprogram használható, melyben meg kell adni a bemeneti fájl és az időjárás fájl elérési helyét. A Simulate gombra kattintva elindítja a szimulációt, a folyamatot a felugró parancssoros ablakban követhetjük. A szimuláció befejezése után a segédprogrammal a kimeneti fájlok megnyitását is egyszerüen elvégezhetjük.

\section{AZ ALKALMAZÁSOK ELKÉSZÍTÉSE}

\section{A. Alkalmazás a rétegrendek elkészitéséhez}

Az alkalmazással a bemeneti fájl által tartalmazott anyagokból készíthetünk egyedi rétegrendeket legördülö menük segítségével. A rétegrendek elkészítése után az alkalmazás egy új bemeneti fájlt hoz létre a minta bemeneti fájl alapján. Amennyiben nem készítünk új rétegrendeket, akkor az előre létrehozott rétegrendeket használja fel az alkalmazás.

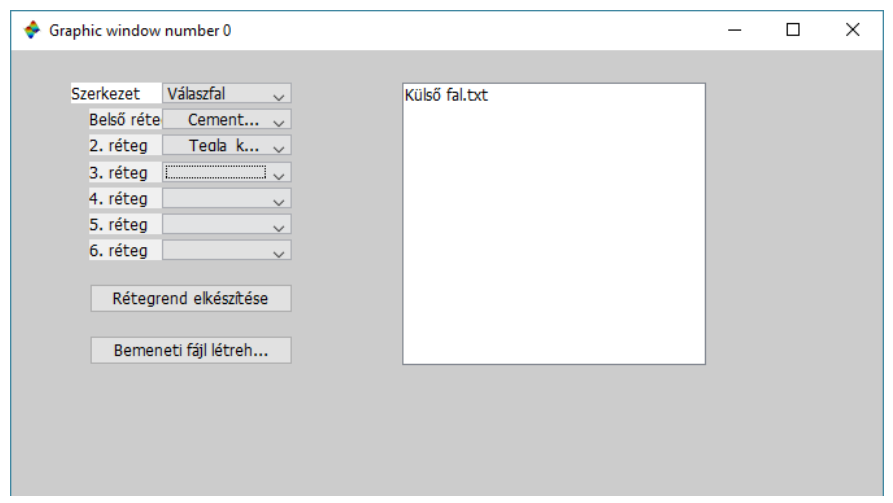

5. ábra: A rétegrendek elkészítésére szolgáló alkalmazás felülete [saját ábra] 


\section{B. Alkalmazás az ajánlások szerinti módositáshoz}

A szerkezet módosításához a rétegrendeket kell kiegészíteni vagy megváltoztatni. A bemeneti fájlt elkészítő alkalmazás a rétegrendek leírásánál üres sorokat hagyott a külső oldali szigetelések nevének beillesztésére. A nyílászárók és a fütési rendszer módosításához az alkalmazás átírja az objektum adatait.

A 'Bemeneti fájl létrehozása' gombra kattintva elkészül a módosított bemeneti fájl. A 'Szimuláció indítása' gomb elindítja az eredeti és a módosított fájlok alapján a szimulációt.

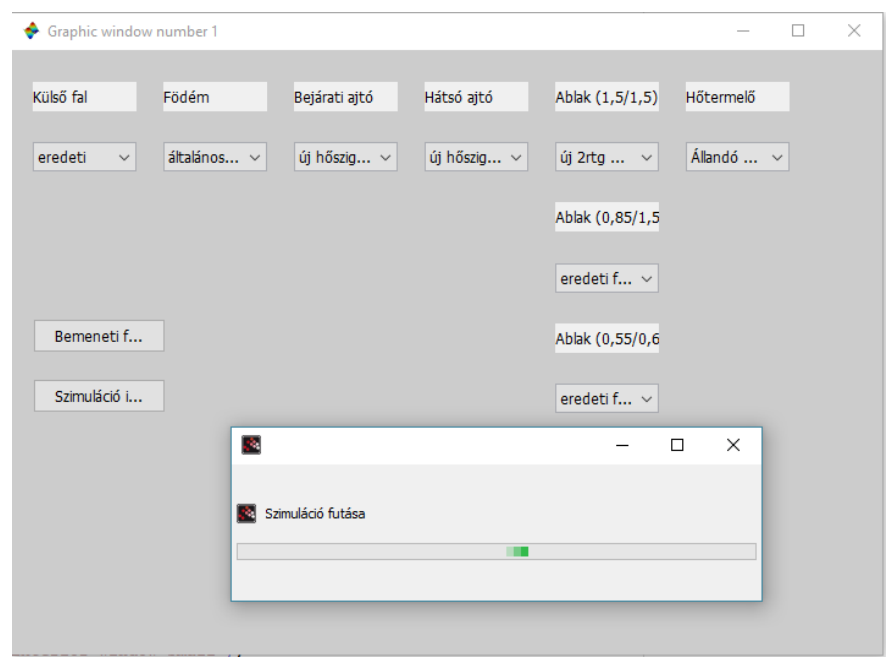

6. ábra: A felújítások szerinti módosításokat elvégző alkalmazás grafikus felülete [saját ábra]

\section{Az eredményeket megjelenitó alkalmazás}

A felújítás hatásainak vizsgálatához az eredeti és a felújított épület hőveszteségeit és az energiaigényeit szeretnénk összehasonlítani. A kimenetet megjelenítő alkalmazás az ezeket az adatokat tartalmazó kimeneti fájlokból olvassák ki az értékeket.

A bemeneti fájl beállításainak megfelelően az eplusout.csv fájl az ablakok hőveszteségeit tartalmazza Joule mértékegységgel és a külső felületek hőveszteségeit Watt mértékegységgel. Az adatok szerkezet-típusként csoportosítása miatt az azonos típusú felületek adatait összeadjuk. Az adatok értelmezhetősége miatt közös mértékegység szükséges. Ehhez átváltjuk a Wattokban kapott értékeket Jouleba.

A világításból, a fütésből és az elektromos berendezésből származó energiafelhasználást az eplusmtr.csv fájlok tartalmazzák. Az adatok mértékegysége egységesen Joule. A csv fájlok vesszővel tagolt adatait változóba olvasva a csvTextScan parancs segítségével tudjuk elválasztani egymástól.

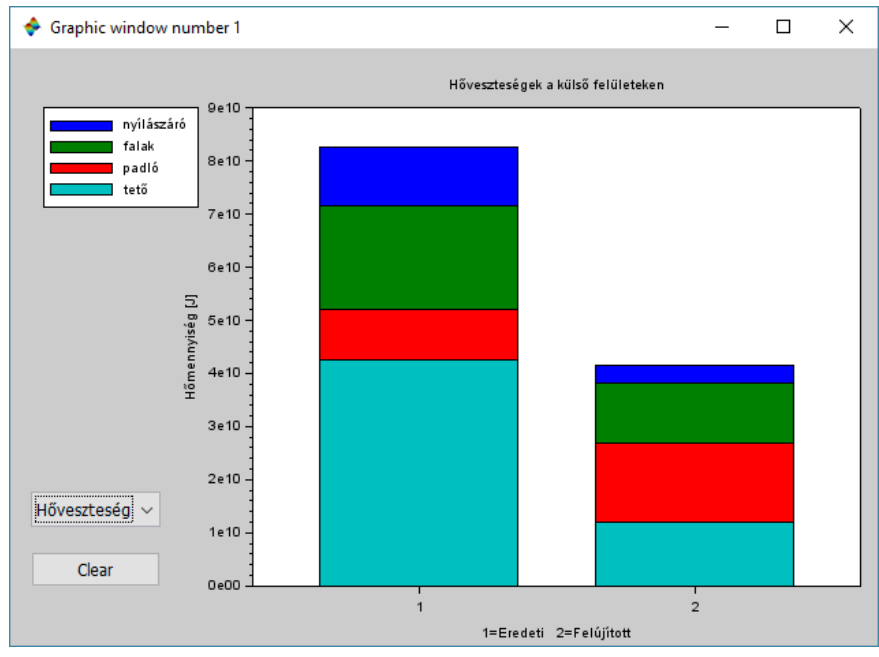

7. ábra: Az eredeti és a módosított épület külső felületeinek hőveszteségének összehasonlítása az alkalmazásban [saját ábra]

A grafikus felület egy rajzterületből és egy legördülő menüből épül fel. A menü értéke alapján lehet váltani a hőveszteségek és az energiaigény megjelenítése között. Az adatok egyszerü szemléltetésére oszlopdiagramot használunk, melyet a bar parancs valósít meg. A diagramok két x értéket vesznek fel (1 és 2), az eredeti és a felújított szerkezet adataihoz. Az adatok értékei az y tengelyen jelennek meg. Ahhoz, hogy a szerkezettípusok és a fogyasztók szerinti adatok ne külön oszlopokban jelenjenek meg, szükség van az oszlopok rendezésére, melyhez a barhomogenize() parancs használható. Így az oszlopokat $x$ értékenként halmozva megjeleníthető az összes energiafelhasználás, illetve az összes hőveszteség.

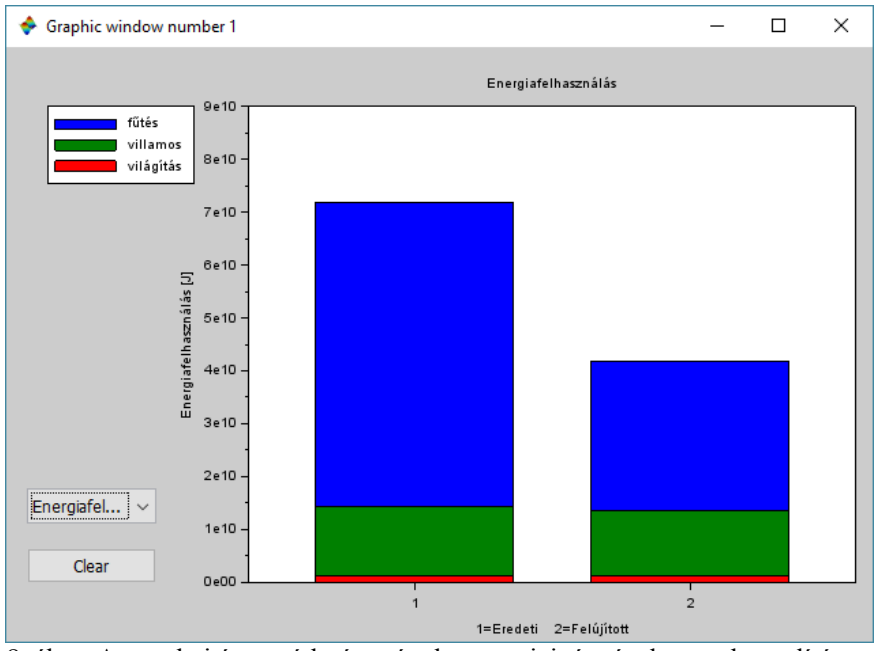

8. ábra: Az eredeti és a módosított épület energiaigényének összehasonlítása az alkalmazásban [saját ábra] 


\section{A szimuláció eredményei}

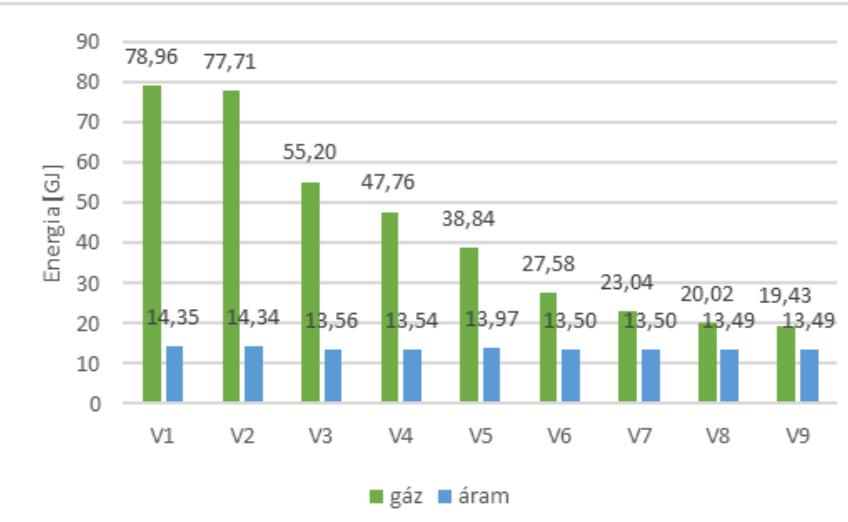

9. ábra: Az épület különböző változatainak szimulációja során kapott éves gáz és villamosenergia fogyasztási adatai [saját ábra]

A diagramon (9. ábra) a különböző változatok éves gáz és villamosenergia felhasználásainak szimuláció során kapott értékei láthatók. Megfigyelhető, hogy a teljes általános felújításig (V6) a felújítás egyes elemeinek elvégzése önállóan is jelentősen csökkenti a fütési energiaigényt. A villamos energiafelhasználásban nem következik be jelentős változás, mivel a használati melegvíz igény független a módosított tényezőktől. A kismértékü változás a fütési rendszer szivattyújának energiafogyasztásából ered.

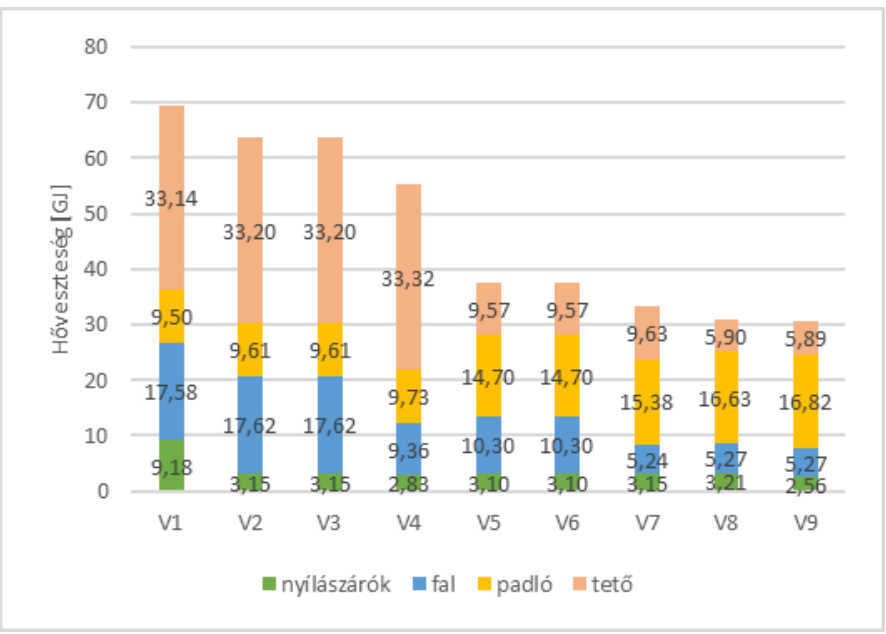

10. ábra: Az épületváltozatok külső felületeinek szimulációi során kapott hőveszteség tényezői [saját ábra]

A második diagramon (10. ábra) a felületeken fellépő hőveszteségek láthatók. Az épület jelenlegi állapota szerint a legnagyobb hőveszteség a födémen keresztül lép fel, ezáltal a legnagyobb változást ennek szigetelésével érhetjük el. Az eredeti nyílászárók korábban elvégzett cseréjével az itt fellépő hőveszteség körülbelül az 1/3-ra csökkent (34\%), a felújítás során kimaradt kisebb ablakok cseréjével vagy a mélyfelújítási szintnek megfelelő nyílászárók beépítésével további javulás érhető el, de ez a többi szerkezet korszerüsítéséhez képest elhanyagolható.

A legnagyobb csökkenés az energiafelhasználásban, ezáltal az energiaköltségben a teljes mélyfelújítás elvégzésével érhető el. Ehhez közeli eredmények érhetök el, amennyiben a teljes általános felújítást kiegészítjük a külső falak vagy a födém szigorúbb előírás szerinti felújításával.

\section{E. Energetikai tanúsítvány}

Az Európai Unió az energiafogyasztás csökkentésére irányuló célkitüzések teljesítése érdekében a tagállamok számára kötelezővé tette az épületek energiahatékonyságát igazoló tanúsítási rendszerek létrehozását. A tanúsítványoknak tartalmaznia kell az épület energiahatékonyságára vonatkozó adatokat és referenciaértékeket, hogy az épület tulajdonságai összehasonlíthatók és értékelhetők legyenek. [6]

$\mathrm{Az}$ energetikai tanúsítvány meghatározását az épületek energetikai jellemzőinek tanúsításáról szóló 176/2008. (VI. 30.) Korm. rendelet tartalmazza. Az épületek energetikai besorolása az épületre jellemző és a megengedett fajlagos primer energia fogyasztás értékek százalékos aránya alapján történik. A fajlagos primer energia igény követelményértékét a 7/2006. (V.24.) TNM rendelet 6. melléklete tartalmazza, mely a közel nulla energiaigényü épületek követelményszintjét írja le. [7] [8]

\section{F. Alkalmazás az energetikai besoroláshoz}

$\mathrm{Az}$ energetikai tanúsításhoz szükséges adatokat a szimuláció bemeneti és az eplustbl.csv fájlból olvassuk ki. Ezek tartalmazzák az épületre jellemző adatokat. A számításokat a 7/2006. (V.24.) TNM rendelet szerint végzi el az alkalmazás. A számítás végén a fajlagos hőveszteségtényező és a fajlagos primer energia igényt kapjuk eredményként. A követelményértékeket a rendelet közel nulla energiaigényre vonatkozó 6 . melléklete tartalmazza.

A besorolás alapjául a fajlagos primer energia igény és annak követelményértékének százalékos aránya szolgál. Ezt a viszonyt vizsgálva besorolható az épület. A számolt értékek mellett megjelenítjük a szimuláció során kapott energiafogyasztási eredményekből számolt primer energiafelhasználást. Ehhez a fogyasztási adatot meg kell szorozni az energiahordozó szerinti primer energia átalakítási tényezővel.

$$
E_{p}^{w}=E_{f}-1+E_{R W W}-2,5+E_{u \mathbb{P}}-1,8
$$




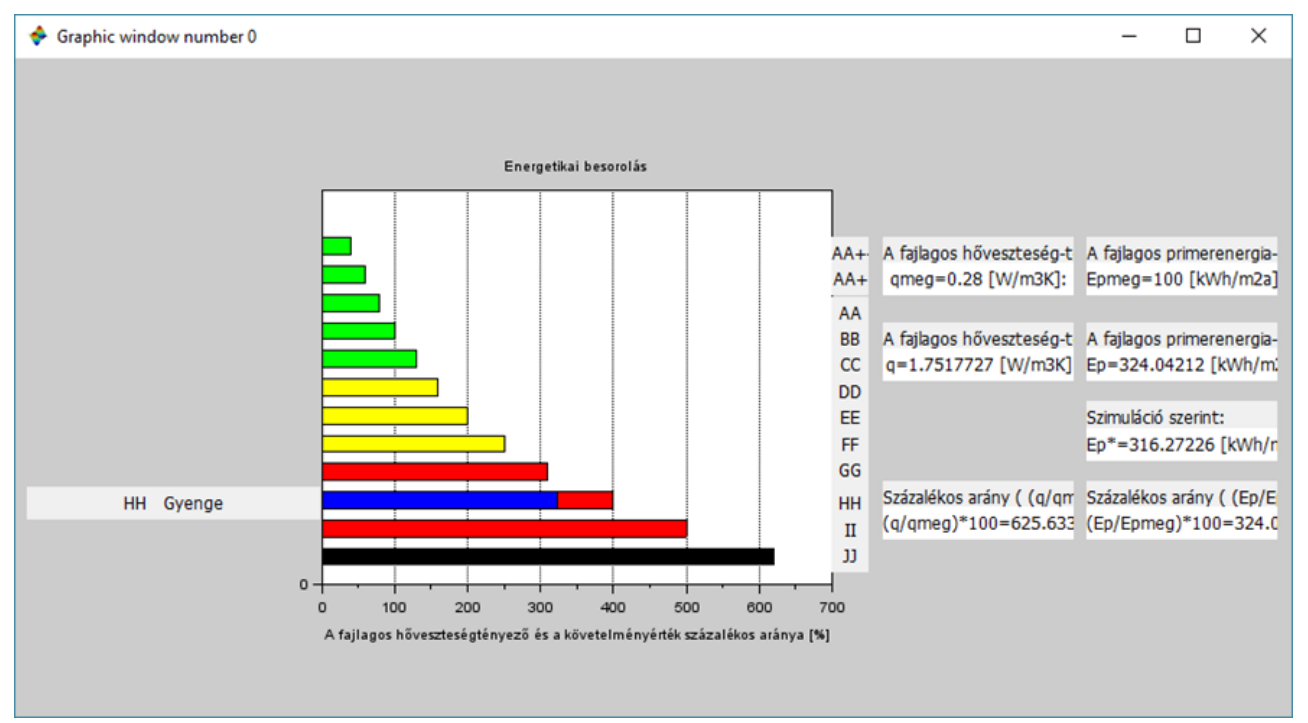

11. ábra: A modellezett épület jelenlegi állapota szerinti energetikai besorolása az alkalmazásban [saját ábra]

A rendelet szerint számolt és a szimulációs eredmények között eltérések tapasztalhatók, melynek oka az, hogy a rendelettel ellentétben a szimuláció a valós használat alapján számolja a fogyasztási adatokat, a rendelet pedig az általánosan jellemzö értékeket használja fel meg.

Az épület jelenlegi állapotában a gyenge $(\mathrm{H})$ kategóriába tartozik. A teljes mélyfelújítás elvégzése után az épület besorolása az átlagosnál jobb (EE) minösítésbe tartozna, ahogyan a 12. ábrán látható. Ennek a felújítási szintnek célja a közel nulla energiaszint elérése, azonban az ajánlást tartalmazó tipológiai dokumentum a 2014-es viszonyoknak felel meg. A fajlagos primer energia igény követelményértékét és az energetikai besorolás követelményeit az azóta eltelt időszakban szigorították, ezáltal a kedvezőbb besorolás eléréséhez további korszerüsítés, leginkább megújuló energiaforrások felhasználása szükséges. Napjainkban az energetikai besorolás elkészítéséhez statikus számításokat alkalmaznak. A szimuláció során kapott és a rendelet szerint számolt eredmények közötti különbségek elhanyagolhatók, ezért a szimuláció eredmények ebben az esetben nagy pontossággal alkalmazhatóak az energetikai besorolás meghatározására.

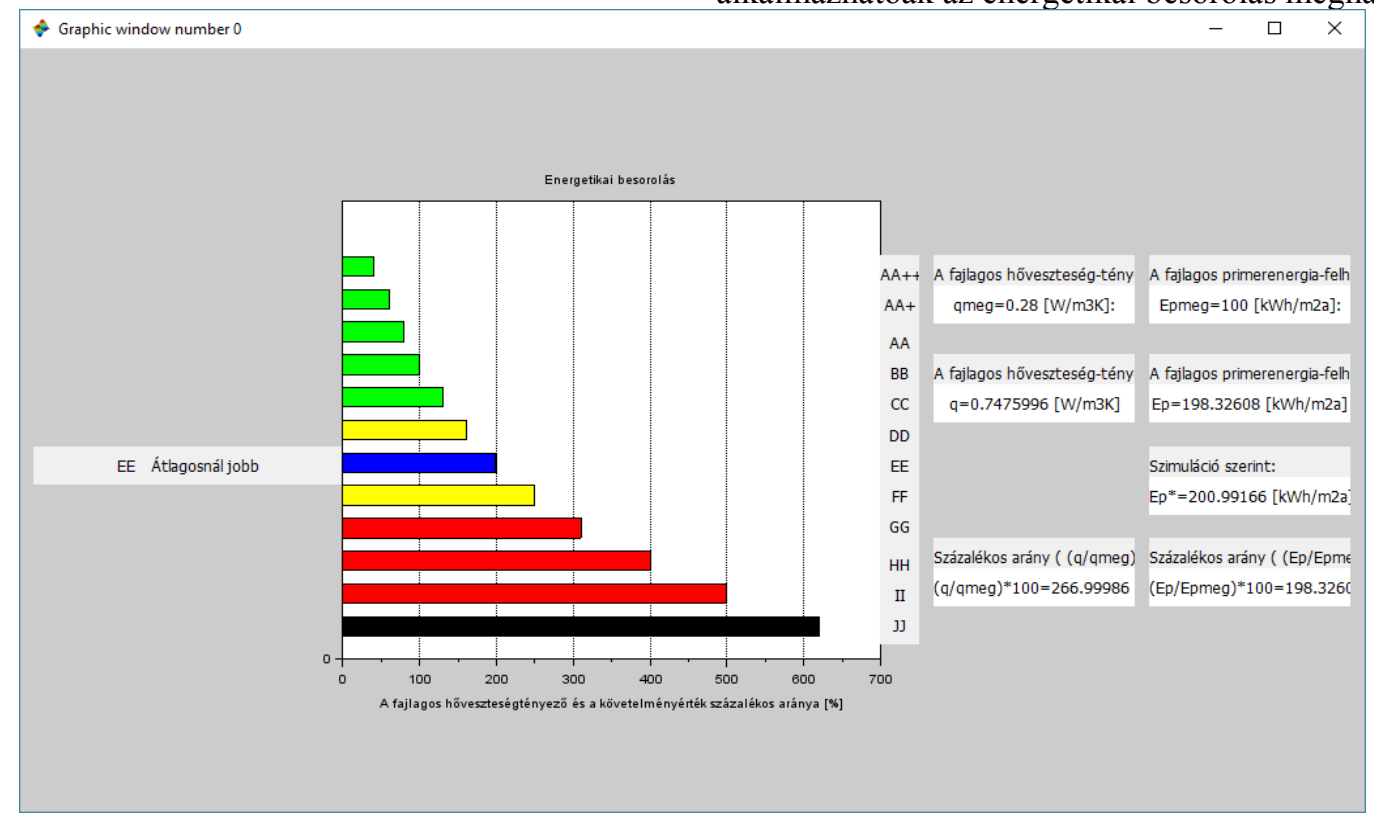

12. ábra: Az épület energetikai besorolása az alkalmazásban a mélyfelújitás elvégzését feltételezve [saját ábra] 


\section{V. ÖSSZEFOGLALÁS}

Az elkészült alkalmazások a kitűzött cél megvalósítására alkalmasak. A vizsgálati eredmények felhasználhatóak az épület jövőbeli korszerüsítésének megtervezésére, valamint az azonos típusú lakóépületekről hozzávetőleges információt biztosítanak. Összességében elmondható, hogy az energetikai szimuláció megfelelő és részletes adatokat biztosít az épületek energetikai tulajdonságainak leírásához és az energetikai tanúsítvány elkészítéséhez. Ezek a scilab szoftverrel speciális igényeknek megfelelően feldolgozhatók a szimuláció eredményei.

\section{KÖSZÖNETNYILVÁNÍTÁS}

A publikáció/prezentáció/poszter elkészítését az EFOP3.6.1-16-2016-00022 számú projekt támogatta. A projekt az Európai Unió támogatásával, az Európai Szociális Alap társfinanszírozásával valósult meg.

\section{HIVATKOZÁSOK}

[1] T. Csoknyai, S. Hrabovszky-Horváth, M. Seprődi-Egeresi és G. Szendrő, „Lakóépület tipológia Magyarországon,” BME, Budapest, 2014.
[2] „Building Energy Modeling | Department of Energy,” [Online]. Available: https://energy.gov/eere/buildings/building-energy-modeling-0. [Hozzáférés dátuma: 21. október 2017.].

[3] „OpenStudio | OpenStudio,” [Online]. Available: https://www.openstudio.net/. [Hozzáférés dátuma: 21. október 2017.].

[4] „EnergyPlus | EnergyPlus,” [Online]. Available: https://energyplus.net/. [Hozzáférés dátuma: 21. október 2017.].

[5] „Scilab.io - Open Source Modeling, Simulation and Scientific Data Analysis,” [Online]. Available: http://scilab.io/. [Hozzáférés dátuma: 21. október 2017.].

[6] „AZ EURÓPAI PARLAMENT ÉS A TANÁCS 2010/31/EU IRÁNYELVE," [Online]. Available: http://eur-lex.europa.eu/legalcontent/HU/TXT/PDF/?uri=CELEX:32010L0031\&from=HU. [Hozzáférés dátuma: 22. november 2017.].

[7] „,7/2006. (V. 24.) TNM rendelet,” Magyar Közlöny Lap- és Könyvkiadó Kft.

[8] „176/2008. (VI. 30.) Korm. rendelet,” Magyar Közlöny Lap- és Könyvkiadó Kft.

[9] „Introduction to Building Simulation and EnergyPlus,” [Online]. Available: https://energyplus.net/support. [Hozzáférés dátuma: 21. október 2017.]. 